\title{
Health Promotion as Early Holistic-Integrative Childhood Development Efforts
}

\author{
$1^{\text {st }}$ Tri Sunarsih \\ Midwifery Departemnt \\ Universitas Jenderal Achmad Yani \\ Yogyakarta \\ Yogyakarta, Indonesia \\ are_she79@yahoo.com
}

\author{
$2^{\text {nd }}$ Ekawati \\ Midwifery Departemnt \\ Universitas Jenderal Achmad Yani \\ Yogyakarta \\ Yogyakarta, Indonesia \\ ekawati_1412@yahoo.com
}

\author{
$3^{\text {rd }}$ Dian Puspitasari \\ Midwifery Departemnt \\ Universitas Jenderal Achmad Yani \\ Yogyakarta \\ Yogyakarta, Indonesia \\ dian.ayaniyka@gmail.com
}

\begin{abstract}
Child growth is not focused on physical health but also on the development of comprehensive in early childhood psychic. A holistic and integrative approach is basically able to build cross-cutting coordination to solve the problem. This study was aimed to determine the influence of health promotion as early holistic-integrative childhood development efforts at play group, integrated health post and Bina Keluarga Balita Cempaka in Krapyak Kulon Panggungharjo, Sewon, Bantul. This was a quantitative study with a quasi-experiment nonequivalent pretest - posttest group design. The data analysis was using a Paired T-Test. The Sig (2-tailed), Paired T-test with value $=0.000$, meant that there was a difference beetween pretest and posttest results. Discussion: Based on the value of the mean posttest outweigh the pretest meant that there was a growing understanding of the participants towards the material presented.
\end{abstract}

Keywords - health promotion, early childhood development of integrative holistic

\section{INTRODUCTION}

The main pillar of the progress of a nation is highly determined by the quality of the resources Division his i.e. human resources (HR) have a tough, physical, and mental health in addition to the intelligentsia level, emotional maturity, and spiritual. Quality of human resources is very determined in the first years of its development, from fetus to children aged 6 years. Experts called it a "golden period" (masa emas), "window of opportunity" (jendela kesempatan) [1].

Handling of early childhood in Indonesia to date indeed felt not optimal. There are a number of factors that also affect. Related factors of population and population distribution i.e. data in 2009 showed that the early childhood population totaled 28,854,400 Indonesia occupied the proportion amounted to $13 \%$ of the population of Indonesia [2]. Of the population, about $43.7 \%$ lived in urban areas and $56.3 \%$ in rural areas. Of that number, about $57.14 \%$ lived in Java, although its territory only $6.9 \%$ of the territory of Indonesia. Population growth per year is around $1.35 \%$.

Factors related to health and nutrition are for children's health, the full basic immunization coverage has increased over 2007, 2010 and 2013 i.e. be $58.9 \%$ in 2013. The highest percentage $(83.1 \%)$ in Yogyakarta and lowest in Papua (29.2\%). The scope of the grant of vitamin A increase of $71.5 \%$ (2007) become $75.5 \%$ (2013). The highest percentage is in West Nusa Tenggara $(89,2 \%)$ and the lowest in North Sumatra $(52,3 \%)$.

Information regarding toddlers' newborn weight and length is based on documents/records, owned by members of the RT (KIA, KMS, or other children's health record book). As much as $52.6 \%$ of toddlers with birth weight records 45 $\%$ of toddlers with birth length record. Still there was 10.2 percent of babies with low birth weight (LBW), i.e. less than 2,500 grams. This percentage decreased from Riskesdas $2010(11.1 \%)$. The percentage of infants were born with short length $(48<\mathrm{cm})$ high enough, i.e. of $20.2 \%$. If it combined with low birth weight and short birth length, then there are $4.3 \%$ of toddlers who has low birth weight and also has short birth length and the highest prevalence of birth in Papua (7.6\%), while the lowest in the Moluccas (0.8\%).

The percentage of breast feeding in the last 24 hours and without a history of pralecteal food given at the age of 6 months of $30.2 \%$. Less initiation of early breast feeding an hour after the baby was born is $34.5 \%$, highest in West Nusa Tenggara, namely of $52.9 \%$ and lowest in West Papua $(21.7 \%)$. Riskesdas 2013 present information the prevalence of children aged 24-59 months who experience disability. Here is a disability that can be observed, including because of disease or trauma/accident. This data shows that the percentage of children with speech impaired and blind increased nearly 2-fold compared the results of Riskesdas.

The percentage of the umbilical cord care in the way children aged 0 to 59 months with not being given anything up from $11.6 \%)$ into $2010 \quad(24.1 \%)$ in 2013 , but that given the betadine/alcohol still larger $(68.9 \%)$. Percentage never circumcised in girls aged 0-11 years of $51.2 \%$, the highest in Gorontalo (83,7 \%), and lowest in the East Nusa Tenggara $(2.7 \%)$. The toddler growth monitoring that conducted each month show that the percentage of children aged 6-59 months who never weighed in last six months tend to increase from $25.5 \%$ (2007), 23.8 percent (2010) be 34.3 $\%$ (2013) [3].

Factors related to educational level i.e. the average education of the population aged 15 years and over is during 7.47 year with educational stage, $53.4 \%$ passed the elementary school; $19.8 \%$ passed the junior high school; $20.7 \%$ passed the high school; and only $6 \%$ who graduated from university. The $63.3 \%$ of city dwellers passed the junior 
high school; meanwhile the villagers still in 33\%. The $82.9 \%$ of city dwellers aged 16-24 years old passed the junior high school; meanwhile the villagers still in $59.9 \%$.

In addition to those factors there are many problems that haunt the quality of nation's generation such as community development, economy, politics, and the most severe is human moral deterioration that is apart from the accompanying factors like a father dares to rape his child, parents dares to sell their daughter's virginity, parents dares to compel their child to become a prostitute, mother dares to kill or throw away her baby, lewd doctors, lewd shaman, lewd governor, lewd chaplain, lewd pastor, lewd headman. The son killed his father. The father did not acknowledge his son. The husband kills his wife and vice versa. An erotically public show assoy dance even dangdut doleng (a public naked lewd dance). The principal intimates his student, teenagers have already smoke, make a chaos and riot. The ease of accessing the information lead a global penetration regarding lifestyles that not fit with local reality.

Many factors encourage the occurrence of moral deterioration. From the changing times, alcoholic beverages, drugs, economics, politics, globalization, technological advances, up to a factor of invisible hand provides a large participation. Family factors, school environment, the environment of the community, and the community that someone followed, can also trigger the onset of moral deterioration if the environment or the community is not good.

Poor education and the construction of the family and society may also result in the same mentally. These bad circumstances, natural or legally surely will give birth to a weak lost generation, no character, unproductive, and unable to face the challenges of the times. In fact, they will so burden society that exacerbates law and social order.

In order to build the Bantul district suffered damage from the quake, the Government compiled the Bantul district development programs in all areas of so-called "Bantul bounce back." One such program is tackling nutritional problems in toddlers [4]. These efforts are shared responsibility between the community, the family, and the Government, by optimizing the empowerment of parenting a toddler. Community empowerment program in Bantul Regency gave larger roles in families and communities as subjects of development. The family played an important role in parenting a toddler.

In terms of institutional service providers, various service institution have provided services for parental education i.e. BKKBN through its Toddlers Family Development group (BKB), Ministry of national education with early childhood education-based family (parenting education), Ministry of health collaboration with the group of mother of toddler, and so on. Both BKB, family-based Toddler education (PAUD), as well as the group of mother of toddler is a program that aims to increase the knowledge, attitudes, skills of parents and other family members, in a nurturing and fostering a growing swell toddlers through physical stimulation, intelligence, emotional, spiritual and social, through effective interaction between parents with their children.

The understanding about the importance of a holisticintegrative early childhood development from stakeholders, both from policy makers, providers, and communities, including health cadres, and village midwives, is still limited. Whereas the role of the stakeholders will be crucial if they were off to go to the community. The low commitment of the community, especially the government, towards family empowerment (institutions), Lack of information about the importance of parenting, causes less active community too. The knowledge of integrated health post Posyandu Cadres, BKB Cadres, and parents about the process of detection of the growing swell of early childhood that can closely monitor the process of growing swell of early childhood along with the deviations possibility that exist is still limited. From the explanations, this study aimed to determine the influence of health promotion as early holistic- integrative childhood development efforts.

\section{METHOD}

This study was conducted in play group, integrated health post and Bina Keluarga Balita Cempaka in Krapyak Kulon, Panggungharjo, Sewon, Bantul. A total of 44 cadres, were selected by using purposive sampling technique. These studies use quantitative methods with quasi experiment nonequivalent pretest-posttest group design. The data is analyzed using Paired T-Test a quasi-experiment design of nonequivalent. Pretest-posttest group design in this research are as follows:

\section{$\mathrm{O} 1 \mathrm{X} \mathrm{O} 2$}

Description:

$\mathrm{O} 1=$ initial condition examination prior to

intervention $\mathrm{X}=$ training health promotion interventions

$\mathrm{O} 2$ = review final conditions after the intervention

\section{RESULT AND DISCUSSION}

Activities change always requires the participation of the community, but the community as main actor of development, often are in a weak position. The community generally have weak bargaining position in decisionmaking, are weak in the knowledge, attitudes, skills, as well as its perception against any development efforts or changes being offered. Community support is needed, particularly to strengthen the skills of parenting by the parent. Result of research on the influence of training in health promotion as early childhood development efforts are holistic integrative medicine can be seen in the table below:

TABLE I. TEST Results PAired T TEST OF HEALTH PROMOTION

\begin{tabular}{|c|c|c|c|}
\hline \multirow{2}{*}{ Variable } & Pretest & Postest & \multirow{2}{*}{ P value } \\
\cline { 2 - 3 } & \multicolumn{2}{|c|}{ Mean (SD) } & \\
\hline Health promotion & 57.5000 & 85.7895 & .000 \\
& & & \\
\hline
\end{tabular}

The value of the Sig (2-tailed) Value: probability/p value Paired T test with result $=0.000$, meaning there is a pretest and outcome differences posttest. If in view of the value of 
the mean posttest outweigh the pretest. This means that there is a growing understanding of the trainee to the materials submitted.

Community support is needed, particularly to strengthen the skills of parenting the parent. Community support in this research is as a facilitator or agent of change (change agent). These factors include a cadre of integrated health post, BKB cadre, and educators of the early childhood education PAUD. Community empowerment facilitators have an important role in degrading and increase public awareness. A role here is a pattern of behavior and attitudes expected of someone because of his position or status. In addition, the facilitator has a role as motivator and community organizers [5]. Therefore, knowledge of cadres should be nice.

The development of integrative holistic early childhood was implemented by the Cempaka Playgroup, Cempaka integrated health post and Cempaka BKB in Krapyak Kulon, Panggungharjo, Sewon, Bantul by integrating these activities. To improve the ability of both cadres of integrated health post, PAUD educators and BKB cadre, the training of health promotion as early childhood development efforts are holistic integrative have been held. The training was carried out by inviting some of the interviewees who are competent of Bantul district Bappeda agencies Mr. IR. Wahit, MA; Family welfare agency, empowerment of women and family planning Bantul Regency Mr. Drs. Lukas Sumanasa, M.Kes and Mr. Kodrat Untoro, S. Sos; The Head of The Clinic, Sewon II Mr. Hadi Pranoto, $\quad$ SKM., MPH;

Department Of Secondary Education And Non Formal Bantul Regency Mr. Hartanto, S. Dwijono, MM; The Driving Team of PKK Dra. Kristin Agus Praptiwi and PMD Bantul Regency Eri Murniasih, S. Ip as well as our outreach team of Dr. Tri Sunarsih, SST.,M. Kes.

Recognition of the importance of early childhood development in the extinct generation of prevention efforts can be seen from many points of view. Every point of view is that early childhood development is important. Improving understanding to the stakeholders especially the cadres of integrated health post, PAUD educators as well as $\mathrm{BKB}$ cadre who was the main offender in the community against these issues is important thing to be given. Therefore, in the training given material about the importance of the review of the early childhood development of holisticintegrative (religious and juridical review, empirical and theoretical review, economic and cultural), goals, objectives, principles and policy directions of the strategy, the types of services as well as indicators of early childhood development close to holistic-integrative medicine.

The granting of material organization of early childhood development services holistic- integrative medicine given because the program is supporting against prevention program of extinct generation (lost generation) and the reality of the situation is not yet implemented in integrative ways especially on parenting education that is about implementation and the material provided. During this extension in $\mathrm{BKB}$, parenting education to PAUD caregivers, and the mother of a toddler is still running independently. With integration program is expected to provide services in a comprehensive manner in accordance with the needs of parenting by parents both in the family and society. The material presented in the system panel with some related materials namely materials coordination mechanism for planning, implementation, monitoring and evaluation (the management activities, execution of the alignment, the holistic BKB integrative servicing model); integrated services model; and models of early childhood education services Holistic Integrative.

The development of a holistic early childhood also characterized by the existence of continuous service, in this case the service system should be coordinated and integrated manner and provide sustainable services from before the child was born until the age of 8 years. Other features of the PAUD service include holistic and provide comprehensive services include stimulation for infants, education of parents and education in early is done at home and in centers of the services of education and health nutrition, the provision of good and healthy sanitations, legal protection of the child against incorrect treatment including exploitation and violence (2).

PKK and PMD (empowerment of village community) is a movement that has been actively involved as partners of the Government in the implementation of various development programs of the community especially the empowerment of families including the family empowerment towards early childhood development. Material about the PKK's role in early childhood development is a holisticintegrative medicine as well as community participation in development (cadre) early childhood holistic-integrative (understanding the basic concepts of community empowerment, the role and function of the perpetrator community empowerment, persuasive communication skills, facilitation skills, formation and development team, Building Learning Commitment/BLC).

Material concepts, objectives, activities and forms of parenting education is also delivered in training because of parenting that is run during this just based on experience only. The parents think the children will be developed on time without having to be given stimulation. Parents often inhibit the learning process carried out by PAUD educators, due to ignorance of the parents about how to educate children. At the time of BKB execution, parents are also less noticed due to confer with other participants.

Parenting education is a populist program to solve the problem. The general objective of this program is to enhance knowledge, skills or attitudes of parents towards the parenting pattern. Assist parents in developing selfawareness [6][7][8], improved self-confidence [9][10], improves mother-child interaction [8][11] supports and nourishes her children [12][13] in the framework of the development of integrative holistic early childhood. Many of the country's or organization's policy emphasizes parenting education [14][15][16].

Parenting education program that walk is often facilitated by cadres and PAUD educator. Cadres in providing counseling just by reading the module only. There are still many cadres who have not received training on how to give a good counseling, so in this training program organizing material about the inclusion of parenting education (counseling methods, the utilization of media, how to deliver learning activities, and evaluation activities / Plans Followup RTL of counseling activities). 


\section{CONCLUSION}

The development of integrative holistic early childhood was implemented by the Cempaka Playgroup, Posyandu Cempaka and BKB in Krapyak Kulon, Panggungharjo, Sewon, Bantul by integrating these activities. Based on the results of data analysis in the discussion, there is a growing understanding of the participants towards the material presented can be seen from the results of the T-test $p$ value Paired with result $=0.000$. Cadres as well as OLD and as educator community empowerment facilitators have important role in bring up and increase public awareness. Suggestion:

- Facilitator is required to have the ability of qualified in order to convey information to optimally target. Ability namely the capacity of individuals to do various tasks within a job, good intellectual ability as well as physical ability should always be honed by following the various training activities that support the development of integrative holistic early childhood.

- Set up the mechanisms of coordination, basic tasks, and the function and form of the partnership each traffic sector. In addition, it also increases the further integration of the cooperation start of planning, preparation, implementation, monitoring to evaluate simultaneously.

- Synergized activity so that such activities can support and enhance each other, not only regarding the time, place, and the means of their implementation, but more important is the material provided. To support the readiness of parents in applying holistic parenting.

\section{REFERENCES}

[1] D. K. R. Indonesia, "Kebijakan Nasional Promosi Kesehatan.” 2005.

[2] Bappenas, "Pembangunan Daerah Dalam Angka 2013," Bappenas, 2013.
[3] K. K. R. Indonesia, "Riset Kesehatan Dasar 2018.” 2018.

[4] P. D. I. Kesehatan, Dinas Yogyakarta, "Profil Kesehatan Provinsi D.I.Yogyakarta Tahun 2011,” 2012.

[5] F. Fagbeminiyi, "The Role of Parents in Early Childhood Education: A Case Study of Ikeja, Lagos State, Nigeria," Glob. J. Hum. Soc. Sci., vol. 11, no. 2, 2011.

[6] A. Rahman, Z. Iqbal, C. Roberts, and N. Husain, "Cluster randomized trial of a parent-based intervention to support early development of children in a low-income country," Child. Care. Health Dev., vol. 35, no. 1, pp. 56-62, 2008.

[7] X. Jin, Y. Sun, F. Jiang, J. Ma, C. Morgan, and X. Shen, "Care for Development" Intervention in Rural China: A Prospective Follow-up Study,” J. Dev. Behav. Pediatr., vol. 28, no. 3, pp. 213-218, 2007.

[8] P. S. Klein and H. Rye, "Interaction-oriented Early Intervention in Ethiopia The MISC Approach," Infants Young Child., vol. 17, no. 4, pp. 340-354, 2004.

[9] A. G. Abesha, "Effects of Parenting Styles, Academic Self-Efficacy, and Achievement Motivation on the Academic Achievement of University Students in Ethiopia,” Dissertation, 2012.

[10] S. Kendall, L. Bloomfield, J. Appleton, and K. Kitaoka, "Efficacy Of A Group-Based Parenting Program On Stress And Self-Efficacy Among Japanese Mothers: A Quasi-Experimental Study," Nurs. Heal. Sci., vol. 15, pp. 454-460, 2013.

[11] L. Lee, C. Griffi, P. Glossop, and V. Eapen, "The Boomerangs Parenting Program for Aboriginal parents and their young children," Australas. Psychiatry, vol. 18, no. 6, pp. 527-534, 2010.

[12] S. J. Smith, "The Development Of A Family Life Education Manual For Teaching Parenting Skills To Incarcerated Fathers," A Thesis Miami Univ., 2005.

[13] G. J. Smith, "Parenting Effects on Self-Efficacy and Self-Esteem in Late Adolescence and How Those Factors Impact Adjustment to College," Pap. Present. Annu. Meet. East. Psychol. Assoc. Philadelphia, pp. 23-25, 2007.

[14] Unicef, "Programming Experiences in Early Child Development," no. November, 2006.

[15] K. P. Nasional, Pedoman Penyelenggaraan Pendidikan Anak Usia Dini Berbasis Keluarga. 2012.

[16] Bappenas, "Pedoman Umum Pengembangan Anak Usia Dini Holistik-Integratif," 2012 